Dhaka Univ. J. Biol. Sci. 21(2): 169-175, 2012 (July)

\title{
RELATIONSHIPS BETWEEN SOIL PHYSICO-CHEMICAL PROPERTIES AND TOTAL VIABLE BACTERIAL COUNTS IN SUNDERBAN MANGROVE FORESTS, BANGLADESH
}

\author{
Mohammad Zabed Hossain*, Chaman Binta Aziz and Mihir Lal Saha \\ Department of Botany, University of Dhaka, Dhaka 1000, Bangladesh
}

Key words: Bacterial colony counts, Soil physico-chemical properties, Sunderban mangrove forests

\begin{abstract}
Although soil bacterial communities are one of the important biotic components that influence decomposition and nutrient mineralization in the terrestrial ecosystems, factors driving this biotic community in the Sunderban mangrove forests are not well studied. The present study examined the importance of soil physico-chemical properties in driving soil bacterial communities in the Sunderban mangrove forests, Bangladesh. Soils were collected from 12 locations under four sites, namely Koromjal, Kotka, Hironpoint, and Dublarchar of Sunderban forests. Results showed a large range of variation in total bacterial colony counts $\left(7.65 \times 10^{4}-14.5 \times 10^{4} \mathrm{cfu} / \mathrm{g}\right.$ soil), soil moisture $(9.0-27.0 \%)$, total nitrogen $(0.057-0.158 \%)$, available nitrogen $(0.504$ $2.016 \mu \mathrm{g} / \mathrm{g}$ soil), soil salinity (20.99 - $34.99 \mathrm{mg}$ chloride/g soil), and organic carbon $(0.460-0.885 \%)$. Data of the present study revealed that the number of total viable bacterial count was significantly and positively correlated only with total nitrogen content in soil indicating that total nitrogen content is the major driving factor of bacterial communities in the Sunderban mangrove forest soils.
\end{abstract}

\section{Introduction}

Soil bacteria are one of the important biotic components that influence decomposition and nutrient mineralization in the terrestrial ecosystems ${ }^{(1)}$. Although studies on examining the factors that influence the soil microbial communities in various ecosystems such as agricultural fields, grasslands and forests are substantial ${ }^{(2,3)}$, relatively less information is available on the relationship between soil properties and microbial communities in mangrove forest soils that are characteristically different from other terrestrial ecosystems.

Mangroves are among the most productive coastal ecosystems in the world that protect coastal people from natural calamities and support livelihood $(4,5)$. The Sunderban mangrove forests is the largest single block of the tidal halophytic mangrove forest of the world.(6) Of the total area of Sunderban forests that lies in the Ganges-Brahmaputra belt, $60 \%$ lies in Bangladesh with about $3,726 \mathrm{~km}^{2}$ and the rest is in India( ${ }^{(7)}$. Due to various

*Corresponding author:<zabed@du.ac.bd>. 
anthropogenic activities, this forest is now under various stresses such as increased salinity and alteration in other physical and chemical composition in soil and water. Such changes in the soil properties are likely to affect the microbial communities in soil and hence the ecosystem properties including organic matter decomposition, nutrient mineralization and vegetation above the $\operatorname{ground}^{(8)}$.

Mangroves provide a unique ecological environment for diverse bacterial communities ${ }^{(5)}$. Natural causes including tidal variations and salinity as well as intense human activities such as transportation through ships, barges and the accidental spills are notably responsible for the diverse microflora in the marine coastal ecosystem ${ }^{(9)}$. Bacteria largely influence nutrient cycling and thus contribute to soil and vegetation patterns.(1) Subsurface bacterial communities may sequester nutrients and hold them within nutrients limited mangrove. However, although some reports on the relationship between soil microbial communities and soil properties are available in the Indian part of Sunderban ${ }^{(4,5,9)}$, relatively less attention has been paid on the topic in Bangladesh part of Sunderban mangrove forests. The objectives of the present study were to study the bacterial population size by counting total viable bacteria and to examine the relative importance of the various physico-chemical properties in driving bacterial colony counts in the Sunderban mangrove forest soils.

\section{Materials and Methods}

Study site description and soil sampling: In order to ensure a large range of variation in soil physico-chemical properties and bacterial colony counts present in the samples, soils

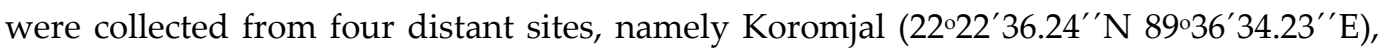

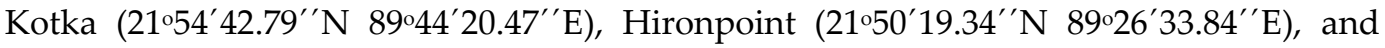
Dublarchar $\left(21^{\circ} 44^{\prime} 06.91^{\prime \prime} \mathrm{N} 89^{\circ} 28^{\prime} 11.21^{\prime \prime} \mathrm{E}\right)$ in the Sunderban mangrove forests of Bangladesh (Fig. 1). Then, from each of the four sites, three locations, $50 \mathrm{~m}$ distant from each, were selected to collect soil samples. Thus, soils were collected from a total of 12 locations.

Soil samples were collected from $0-10 \mathrm{~cm}$ depth and kept in a plastic bag. After collection, soil samples were brought to the laboratory and separated into two subsamples; one for bacteriological analysis that was kept in a refrigerator and the other one for the analysis of soil physico-chemical properties. The collected soils were sieved through a $2 \mathrm{~mm}$ mesh screen to remove plant roots, rocks, and macrofauna. After sieving, soil samples were analyzed to characterize their physico-chemical properties. Soil sampling was done in September, 2008.

Analysis of soil physico-chemical properties: Soil moisture content (\%) was determined by weight loss at $65^{\circ} \mathrm{C}$ for $24 \mathrm{~h}$. The $\mathrm{pH}$ of the soil was measured in a soil water suspension (1 :2, soil : water). Total nitrogen (\%) was determined by Kjeldahl method following extraction from $2 \mathrm{~g}$ soil with conc. $\mathrm{H}_{2} \mathrm{SO}_{4}{ }^{(10)}$. Available nitrogen content was 
also determined by Kjeldahl method following extraction from $10 \mathrm{~g}$ dry soil using $1 \mathrm{~N}$ $\mathrm{KCl}$ solution. Organic carbon content (\%) of the soil was determined by Wakley and Black method using $1 \mathrm{~g}$ soil ${ }^{(10)}$. Organic matter (\%) was determined by multiplying the value of organic carbon by 1.724 (Van Bemmelen factor). Soil salinity was determined as chloride content by following methods described elsewhere ${ }^{(11)}$.

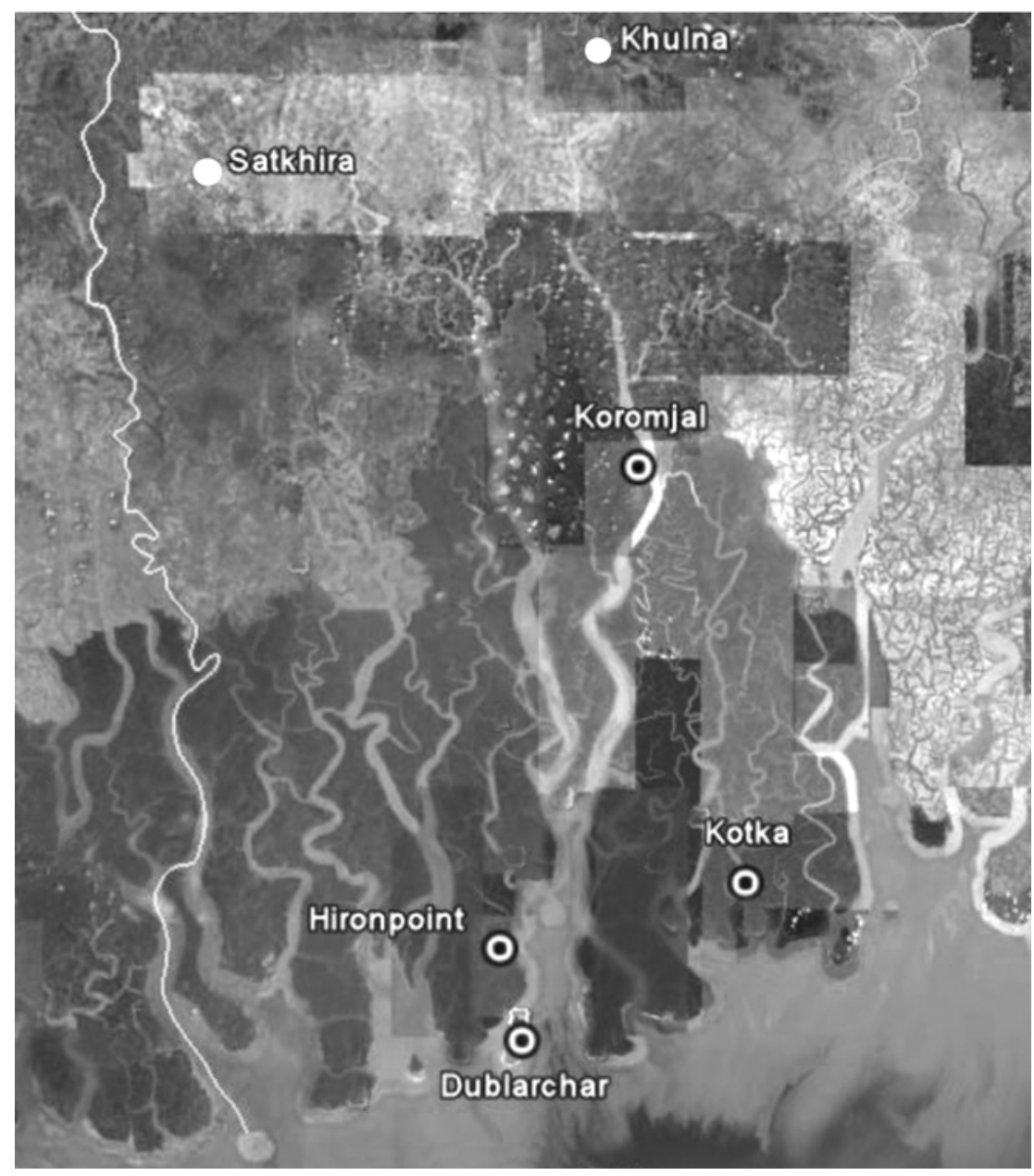

Fig. 1. Map showing the four sites, namely Koromjal, Kotka, Hironpoint and Dublarchar (as indicated by round symbols) in the Sunderban mangrove forests selected for collection of soils in the present study.

Bacteriological analysis: Nutrient agar medium was used for the enumeration of bacteria present in soil samples. The $\mathrm{pH}$ was adjusted before addition of agar and sterilization. Serial dilution plate technique was used for the isolation of microorganisms. One gram sample was diluted $(1: 100)$ with $100 \mathrm{ml}$ distilled water in a sterile conical 
flask and shaken well. One $\mathrm{ml}$ of this suspension was transferred to $9 \mathrm{ml}$ of sterile water for tenfold $(1: 10)$ dilution and by following serial dilutions further diluted up to $10^{5}$ times.

Plating in duplicate plates was made for each diluted sample. One $\mathrm{ml}$ of each of the diluted sample was taken in a sterilized Petri dish by pipette. Then, molten agar medium was poured and mixed thoroughly by rotating the Petri dish, first in one direction and then in the opposite direction.

After setting the medium, the plates were inverted and incubated at $37^{\circ} \mathrm{C}$ for $48 \mathrm{~h}$ in an incubator (Memmert $\mathrm{GmbH}+\mathrm{Co} \mathrm{Kg} 8540$ Schwabach). After $48 \mathrm{~h}$ of incubation, the plates having well discrete colonies were selected for counting. The selected plates were placed on a colony counter (Digital colony counter, DC-8OSK 1000086, Kayagaki, Japan) to count the number of colonies.

\section{Results and Discussion}

Data obtained on soil physico-chemical properties and the bacterial colony counts of the 12 locations are shown in Table 1. Soil moisture contents varied largely with the highest value of $27 \%$ found in Kotka and it was three times higher than the lowest value of $9 \%$ found in Dublarchar. Soil $\mathrm{pH}$, on the other hand, did not vary largely among the locations studied. The highest $\mathrm{pH}$ value (8.02) was found in Hironpoint and the lowest (7.28) was found in Dublarchar. The highest values for organic carbon and organic matter were double ( 0.513 and $0.885 \%$, respectively) found in Koromjal and Dublarchar compared to the lowest values $(0.267$ and $0.460 \%$, respectively) found in Kotka. The highest value of total nitrogen content was about three times higher $(0.158 \%)$ found in Koromjal than that of the lowest value $(0.057 \%)$ found in Kotka. The highest value of available nitrogen $(2.016 \mu \mathrm{g} / \mathrm{g}$ soil) found in Hironpoint was about four times higher than the lowest value $(0.504 \mu \mathrm{g} / \mathrm{g}$ soil) found in Koromjal and Dublarchar. Soil salinity varied one and a half times between lowest (20.99 mg chloride/g soil) found in Kotka and highest values (34.99 mg chloride/g soil) found in Koromjal. Bacterial population size as measured by counting viable bacterial colony also varied largely among the 12 locations taken under study. The average number of total bacterial colony was higher in Koromjal site than that in the Hironpoint site (Fig. 2). The highest value of total viable bacterial count was $14.5 \times 10^{4}\left(\mathrm{cfu} / \mathrm{g}\right.$ soil) found in Koromjal and the lowest value was $7.65 \times 10^{4}$ (cfu/g soil) found in Hironpoint (Table 1).

Coefficients of correlation between bacterial colony counts with the soil physicochemical properties are shown in Table 2. There was no significant correlation present among the soil physico-chemical properties measured in the present study area (data not shown). Among the physico-chemical properties measured, only soil total nitrogen (\%) content showed a significant positive correlation with the soil viable bacterial counts $(\mathrm{r}=$ $0.718, \mathrm{p}>0.01)$. 
Table 1. Soil physico-chemical properties and the bacterial colony counts of the 12 locations under four sites, namely Koromjal, Kotka, Dublarchar and Hironpoint in the Sunderban mangrove forests.

\begin{tabular}{clcccccccc}
\hline $\begin{array}{c}\text { Loca- } \\
\text { tion }\end{array}$ & Site & $\mathrm{pH}$ & $\begin{array}{c}\text { Mois-ture } \\
\text { content }(\%)\end{array}$ & $\begin{array}{c}\text { Organic } \\
\mathrm{C}(\%)\end{array}$ & $\begin{array}{c}\text { Organic } \\
\text { matter } \\
(\%)\end{array}$ & $\begin{array}{c}\text { Total } \\
\mathrm{N}(\%)\end{array}$ & $\begin{array}{c}\text { Available } \\
\mathrm{N}(\mu \mathrm{g} / \mathrm{g})\end{array}$ & $\begin{array}{c}\text { Salinity } \\
(\mathrm{mg} \\
\text { chloride } / \mathrm{g})\end{array}$ & $\begin{array}{c}\text { Bacterial } \\
\text { colony } \\
(\mathrm{cfu} / \mathrm{g})\end{array}$ \\
\hline 1 & Koromjal & 7.66 & 23 & 0.513 & 0.885 & 0.158 & 0.504 & 34.99 & $14.5 \times 10^{4}$ \\
2 & Koromjal & 7.68 & 25 & 0.452 & 0.779 & 0.158 & 1.512 & 26.99 & $11.8 \times 10^{4}$ \\
3 & Koromjal & 7.65 & 24 & 0.452 & 0.779 & 0.095 & 1.008 & 23.99 & $13.0 \times 10^{4}$ \\
4 & Kotka & 7.72 & 27 & 0.267 & 0.460 & 0.057 & 1.764 & 22.99 & $11.3 \times 10^{4}$ \\
5 & Kotka & 7.69 & 25 & 0.267 & 0.460 & 0.069 & 1.764 & 24.99 & $9.7 \times 10^{4}$ \\
6 & Kotka & 7.74 & 23 & 0.308 & 0.531 & 0.076 & 2.016 & 20.99 & $8.6 \times 10^{4}$ \\
7 & Dublarchar & 7.31 & 13 & 0.329 & 0.566 & 0.069 & 1.008 & 32.99 & $8.8 \times 10^{4}$ \\
8 & Dublarchar & 7.29 & 9 & 0.452 & 0.779 & 0.069 & 1.764 & 31.99 & $8.9 \times 10^{4}$ \\
9 & Dublarchar & 7.28 & 11 & 0.513 & 0.885 & 0.082 & 0.504 & 30.99 & $8.7 \times 10^{4}$ \\
10 & Hironpoint & 8.00 & 18 & 0.287 & 0.496 & 0.063 & 2.016 & 31.99 & $7.65 \times 10^{4}$ \\
11 & Hironpoint & 8.02 & 20 & 0.411 & 0.708 & 0.082 & 1.512 & 30.99 & $8.15 \times 10^{4}$ \\
12 & Hironpoint & 8.00 & 19 & 0.287 & 0.496 & 0.069 & 1.512 & 31.99 & $8.8 \times 10^{4}$ \\
\multicolumn{2}{l}{ Mean value } & 7.67 & 19.75 & 0.378 & 0.652 & 0.087 & 1.407 & 28.82 & $9.9 \times 10^{4}$ \\
\hline
\end{tabular}

Table 2. Correlation coefficients ( $r$ ) of the physico-chemical properties with the viable bacterial counts $(\mathrm{cfu} / \mathrm{g})$ in the soils of the Sunderban mangrove forests $(\mathrm{n}=12)$.

\begin{tabular}{lc}
\hline Soil physico-chemical properties & $\mathrm{r}$ \\
\hline Moisture content $(\%)$ & $0.542^{\mathrm{ns}}$ \\
$\mathrm{pH}$ & $-0.094^{\mathrm{ns}}$ \\
Total N $(\%)$ & $0.718^{* *}$ \\
Available N ( $\mu$ g/g soil) & $-0.482^{\mathrm{ns}}$ \\
Soil salinity (mg chloride/g soil) & $-0.111^{\mathrm{ns}}$ \\
Organic carbon $(\%)$ & $0.444^{\mathrm{ns}}$ \\
Organic matter $(\%)$ & $0.444^{\mathrm{ns}}$ \\
\hline
\end{tabular}

** and ns indicate significant at $\mathrm{p}>0.01$ and not-significant, respectively.

The results of the present study showed that soil physico-chemical parameters such as soil moisture, total nitrogen, available nitrogen, organic carbon, and salinity measured varied largely among the 12 locations under the four sites of Koromjal, Kotka, Hironpoint and Dublarchar in the Sunderban mangrove forests. Such variation in the soil properties from location to location might be related with the local environmental factors such as micro-climate, vegetation above the ground and disturbances. Number of viable bacterial count was significantly and positively correlated with only the total soil nitrogen content rather than available inorganic nitrogen indicating the importance of the soil total 
nitrogen in driving the bacterial population in the study area. The result of the present study corresponded with the findings of other study that reported that dissolved organic nitrogen and amino acids were more important than inorganic nitrogen for bacteria in the marine habitats ${ }^{(12)}$.

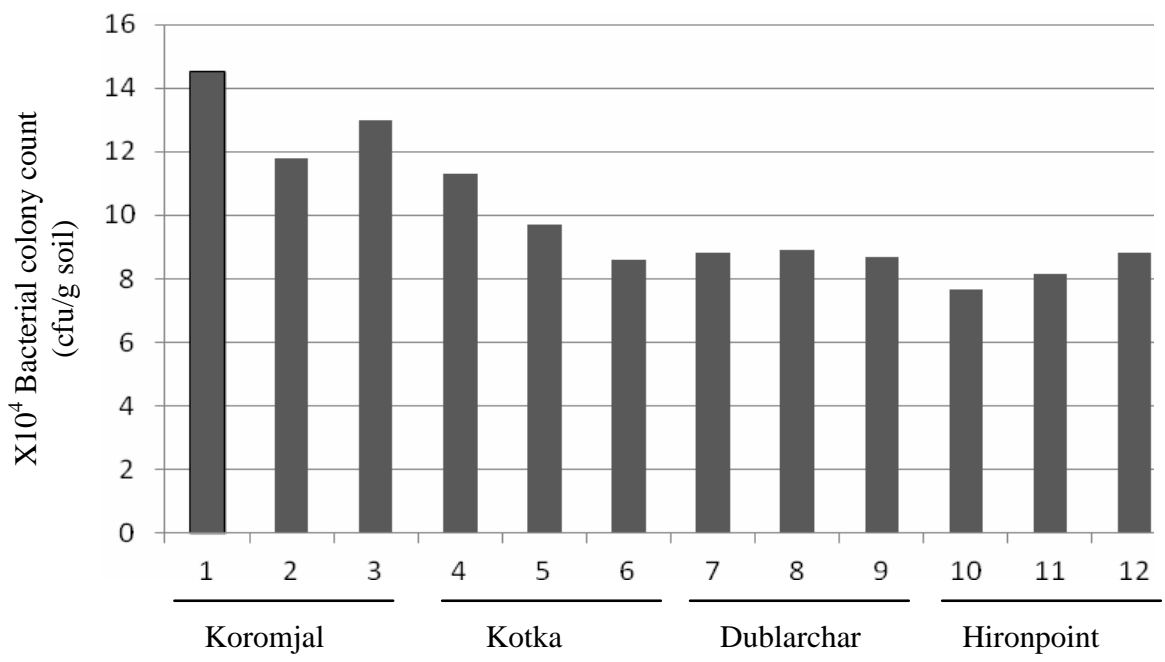

Fig. 2. Total viable bacterial counts (cfu/g) in the soils of 12 locations (1-12) under four sites Koromjal, Kotka, Hironpoint and Dublarchor in the Sunderban mangrove forests.

Data also showed that the average number of viable bacterial colony found in the present study area of Sunderban mangrove forests of Bangladesh was lower $\left(9.99 \times 10^{4}\right.$ $\mathrm{cfu} / \mathrm{g}$ soil $)$ than that in Pichavaram mangrove forest in India $\left(26.8 \times 10^{4}\right.$ to $179.7 \times 10^{4} \mathrm{cfu} / \mathrm{g}$ soil) as reported by other study ${ }^{(4)}$. Such differences in the bacterial population size between these two parts of Sunderban mangrove forests might be related with natural causes including tidal differences and the intense human activities such as destruction of forests, transportation through ships, barges, and the accidental spills ${ }^{(9)}$. The results of the present study also suggest the need of further study in order to understand the dynamics of the bacterial communities in this mangrove forests taking more sampling sites under consideration at temporal scale as well.

\section{References}

1. Bardgett RD. 2005. The Biology of Soil: A community and ecosystem approach. Oxford University Press.

2. Hossain Z and S Sugiyama. 2011. Geographical structure of soil microbial communities in northern Japan: effects of distance, land use type and soil properties. European J. Soil Biol. 47: 88-94.

3. Nusslein K and JM Tiedje. 1999. Soil bacterial community shift correlated with change from forest to pasture vegetation in a tropical soil. Appl. Environ. Microb. 65: 3622-3626. 
4. Kathiresan K. 2002. Why are mangroves degrading? Curr. Sci. 83(10): 1246-1249.

5. Ramanathan AL, G Singh, J Majumdar, AC Samal, R Chauhan, RK Ranjan, K Rajkumar and SC Santra. 2008. A study of microbial diversity and its interaction with nutrients in the sediments of Sunderban mangroves. Indian J. Marine Sci. 37(2) : 159-165.

6. Pasha MK and NA Siddiqui. 2003. Sunderbans, Banglapedia: National encyclopedia of Bangladesh, Asiatic Soc. Bangladesh.

7. Khan MS. 1991. The vegetation of Bangladesh. In: Plant life of south Asia (Ali S.I. and A. Gaffar Eds), pp. 185-192.

8. Wardle DA. 2002. Communities and ecosystems: Linking the aboveground and belowground components. Princeton University Press.

9. Rawte T, M Padte and S Mavinkurve. 2002. Incidence of marine and mangrove bacteria accumulating polyhydroxyalkanoates on the mid-west coast of India. World J. Microb. Biotechnol. 18: 655-659.

10. Black CA. 1965. Methods of soil and plant analysis. Part I and II. American Soc. Agron.

11. Anonymous. 1992. Standard Methods for the Examination of Water and Wastewater. APHA/AWWA/WPCF, Washington DC.

12. Wheeler PA and DL Kirchman. 1986. Utilization of inorganic and organic nitrogen by bacteria in marine systems. Limnol. Oceanogr. 31(5): 998-1009.

(Manuscript received on 17 August, 2011; revised on 26 February, 2012) 